Int. J. Morphol.,

33(3): 1085-1092, 2015.

\title{
Effect of Resveratrol on Mitochondrial Activity in Differentiated Mature Adipocytes
}

\author{
Efecto del Resveratrol sobre la Actividad Mitocondrial en Adipocitos Maduros Diferenciados
}

\author{
Noriega-González, J. E.*; Chirino, Y. I. ${ }^{* *}$; Mata-Miranda, M. M.*******; \\ Vázquez-Zapién, G. J.,***** \& Sánchez-Monroy, V.****,*******
}

NORIEGA-GONZÁLEZ, J. E.; CHIRINO, Y. I.; MATA-MIRANDA, M. M.; VÁZQUEZ-ZAPIÉN, G. J. \& SÁNCHEZ-MONROY, V. Effect of resveratrol on mitochondrial activity in differentiated mature adipocytes. Int. J. Morphol., 33(3):1085-1092, 2015.

SUMMARY: Obesity has reached epidemic proportions, the World Health Organization (WHO) estimates that there are more than 1,000 million overweight adults world-wide. Furthermore, obesity is characterized as an overgrowth of white adipose tissue as a result of adipocyte hypertrophy and hyperplasia. Mitochondria is considered the source of energy within the adipocyte, since it contains the molecular machinery, and it is involved in a large number of metabolic pathways, besides the transformation of chemical energy into adenosine triphosphate. Mitochondria shortage and adipocyte dysfunction result in an excessive accumulation of triacylglycerol in the cytoplasm, which determines an imbalance between energy production and energy expenditure. Resveratrol (RSV) is a polyphenol found in different plants and its effects have been associated with mitochondrial biogenesis. An adipogenesis in vitro model (3T3-L1 preadipocytes) was used, and these cells were differentiated into mature adipocytes. Subsequently the effect of RSV on the adipocytes morphology, the lipid content and mitochondrial activity was evaluated using microscopic and flow cytometry techniques. The effect of RSV on differentiated mature adipocytes, was characterized by the decrease in lipid content and the consequently declination of the mitochondrial activity. 3T3-L1 preadipocytes retained the differentiation ability until passage 18 . The RSV at doses of 25 and $50 \mu \mathrm{M}$ for 48 hours in differentiated mature adipocytes promoted the decreased in lipid content probably due to an increase in mitochondrial activity in the early hours of RSV exposure, causing the consequently declination of mitochondrial activity at the end of 48 hours.

KEY WORDS: Preadipocytes; Differentiated mature adipocyte; Mitochondrial activity; Resveratrol.

\section{INTRODUCTION}

Obesity is defined as body mass index greater than $30 \mathrm{~kg} / \mathrm{m}^{2}$, and it is becoming a major health problem in the world. Obesity has taken epidemic global dimensions; the World Health Organization estimates that there are more than 1,000 million overweight adults, of these about 300 million are obese (Kopelman, 2007). Social change and nutrition transition have turned obesity into a global epidemic.

Economic development, modernization, urbanization and globalization of food markets, are some of the elements that have contributed to the epidemic of obesity, besides the significant decrease in the physical activity, which is associated with the increased use of automated transport, the use of technology at home, among others (WHO, 2013).
Obesity is associated with premature death through the increased risk of many chronic diseases, including type 2 diabetes mellitus (DM2), cardiovascular disease and certain cancers, besides being related with respiratory distress syndrome, chronic musculoskeletal problems, skin diseases and infertility. Obesity is characterized as an overgrowth of white adipose tissue as a result of adipocyte hypertrophy and hyperplasia (Guh et al., 2009). There are two kinds of human adipose tissue, white adipose tissue (WAT) and brown adipose tissue (BAT). The most abundant is the WAT, the same that is distributed throughout the body, it has the ability to expand massively, and it is a heterogeneous tissue since it contains diverse cell types, mostly white adipocyte. These adipocytes are surrounded by fibroblasts, endothelial cells, immune cells and nerves (Cristancho \& Lazar, 2011).

\footnotetext{
* Laboratorio de Embriología, Escuela Médico Militar, Universidad del Ejército y Fuerza Aérea, México D.F., México.

** Unidad de Biomedicina, Facultad de Estudios Superiores Iztacala, Universidad Nacional Autónoma de México, Tlalnepantla, México.

**** Laboratorio de Biología Celular y Tisular, Escuela Médico Militar, Universidad del Ejército y Fuerza Aérea, México D.F., México.

***** CIBA-Tlaxcala, Instituto Politécnico Nacional, Tepetitla, Tlaxcala, México.

****** Laboratorio Multidisciplinario de Investigación, Universidad del Ejército y Fuerza Aérea, México D.F., México.

******** Programa Institucional de Biomedicina Molecular ENMyH, Instituto Politécnico Nacional, México D.F., México.
} 
Adipocytes derive from mesenchymal stem cells so that they can differentiate into myoblasts, chondroblasts, osteoblasts and adipocytes. During the adipocyte life cycle, the cell undergoes alterations as cell shape, cell cycle arrest, clonal expansion and a complex sequence of changes in gene expression, leading to lipids storage and eventually cell death (Gregoire, 2001).

White adipocytes are rounded cells that measure from 10 to 200 microns; these cells contain lipid droplets which push the nucleus and other organelles to the periphery of the cell, this vacuole represents the $95 \%$ of the cell weight. Biological events that lead to obesity are characterized by changes in cellular properties and may include adipocyte hyperplasia, hypertrophy, or both. Adipose tissue serves as the major energy storage in form of triacylglycerol (TAG) releasing fatty acids into the circulation during prolonged fasting and starvation. This tissue is also considered as an active endocrine organ because it releases various hormones and chemokines with endocrine and paracrine functions. Currently adipocytes have been studied with increasing intensity as an essential regulator of body energy homeostasis (Frayn et al., 2006).

Furthermore, the BAT is also constituted by adipocytes, characterized by a high number of mitochondria and multiple small droplets. In this organ the uncoupling protein 1 (UCP1) is expressed, and this protein is involved in the generation of heat through uncoupled mitochondrial respiration from ATP synthesis, and this is the reason that it is considered as a thermogenic organ. During gestation period for humans the development of BAT starts earlier than WAT (2nd quarter). Emphasizing that in adults BAT is lost and/or replaced with WAT (Rosen \& Spiegelman, 2006).

Mitochondria carry out a very important function in cellular bioenergetics and are considered the power source within the adipocyte. In this organelle many reactions take place, some of them are listed below: pyruvate oxidation, oxidation of fatty acids, citric acid cycle (Krebs cycle) and oxidative phosphorylation, any alteration in this metabolic process leads to cellular dysfunction. Abnormal mitochondrial function results in lipid accumulation and insulin resistance, as cells require a balance between mitochondrial ATP synthesis through oxidative phosphorylation, and dissipation of the proton gradient to minimize damage from reactive oxygen species (ROS). Recent molecular studies have shown dramatic changes in mitochondrial content of adipocytes during adipogenesis. Data obtained from analysis of mitochondrial protein expression through two dimensional polyacrylamide gel electrophoresis show a 20-30 fold increase in the abundance of mitochondrial proteins in early stages of differentiation (Bournat \& Brown, 2010).
The promotion of coordinated adipogenesis and mitochondrial biogenesis suggests that the mitochondrion carries out an important role in the differentiation and maturation of adipocytes. This is not only because of the increased needs of the cell during differentiation, it is also due to the substances provided by the mitochondria which support the massive lipogenesis during adipogenesis. Adipocyte mitochondria are energetically critical for adipogenesis. Differentiating cells must generate sufficient ATP for sustained fatty acid synthesis in addition to the ATP demanded for normal cellular activity. In accordance with adipogenesis progresses, there is a significant increase in mitochondrial biogenesis. As a result of this, a large number of mitochondria are found in the cytoplasm. Due to the abundant content of fatty acids deposits, WAT possesses a rise in mitochondrial oxidative activity, that is to say an increase in B-oxidation which provides a major source of ATP for mature adipocytes (De Pauw et al., 2009).

Resveratrol (RSV) (3, 5, 4'-trihidroxistilbeno) belongs to a large group of polyphenols found in various groups of plants. The richest natural source of RSV is the Polygonum Cuspidatum plant, although significant amounts have been found in peanuts, tea Itadori, grapes and red wine (Pervaiz, 2003). Besides its natural form, this compound is available in tablets and it is recommended as a dietary supplement. In recent years, interest in $\mathrm{RSV}$ has substantially increased and its broad biological activity at the cellular level has been demonstrated. The biological properties are listed below: cardioprotective (Hung et al., 2000), anti-neoplastic (Atten et al., 2005), antiinflammatory and anti-oxidant (de la Lastra \& Villegas, 2007). Preclinical studies have suggested that RSV simulates the effects of calorie restriction (Barger et al., 2008).

RSV has shown to reduce lipid synthesis in rat liver and 3T3-L1cells (Picard et al., 2004), furthermore, lipid accumulation in maturing preadipocytes 3T3-L1 decreased. RSV increases the lipolysis and reduces the lipogenesis in mature adipocytes, contributing to the reduction of lipid accumulation in vitro (Rayalam et al., 2008).

RSV effects have been associated with the induction of genes for fatty acid oxidation and mitochondrial biogenesis; the last mentioned protects mice against high fat diet-induced obesity. The effect of RSV on mitochondrial biogenesis has been attributed to activation of RSV on sirtuin 1 (SIRT1), which is a homologous protein of silent information regulator protein (sir2), this protein acts as an oxidized nicotinamide adenine dinucleotide (NAD+) dependent deacetylases enzymes (Lagouge et al., 2006). 
SIRT1 is involved in the control of systemic metabolism via regulation of glucose and lipid homeostasis by deacetylation of various targets, such peroxisome proliferator-activated receptor gamma coactivator-1alpha (PGC-1åß), of the peroxisome proliferator-activated receptor gamma (PPAR) which is an important factor in mitochondrial biogenesis and function, related to mitochondrial metabolism (Gehart-Hines et al., 2007). It has been shown that PGC-12 increases the expression of nuclear respiratory factor (NRF), which are transcriptional factors that regulate the expression of many mitochondrial genes. In addition, PGC-12 coactives and increases the transcriptional activity of NRF1 in target genes (Austin \& St-Pierre, 2012). Subsequently, an important physiological effect on mitochondria was demonstrated (an increase in the uncoupled breathing) conditioned by the increased expression of mitochondrial genes of the respiratory factors mentioned above. In addition, treatment with RSV has produced morphological changes in adipocyte (lipid droplets were decreased) and also increased levels of uncoupling protein 1 (UCP-1) in BAT (Lagouge et al.).

There are few clinical trials that have examined the metabolic effects of consuming RSV. Significant but modest improvements were reported in the following physiological variables and conditions: decrease in insulin resistance, decreased systemic blood pressure and increased metabolic rate. Likewise a reversible effect occurred in lipid accumulation in the liver (hepatic steatosis) (Timmers et al., 2011).

Obesity is a disease that is characterized by hypertrophy of WAT, making it necessary to increase scientific evidence about diet effects on mitochondrial activity in this tissue. In this study we conducted an experimental design based on an in vitro model of preadipocytes 3T3-L1 differentiated to mature adipocytes, we evaluated the effect of RSV on mitochondrial activity and morphology of differentiated mature adipocytes. And we determined that the RSV promotes a decrease in lipid content probably due to an increase in mitochondrial activity at early stage of exposure to RSV treatment.

\section{MATERIAL AND METHOD}

Cell culture and adipocyte differentiation. Murine preadipocyte 3T3-L1 cell line obtained from the American Type Culture Collection (ATCC) were cultured according to the manufacturer's instructions, cells were seeded in 60 $\mathrm{mm}$ dishes (P60). In summary, preadipocytes 3T3-L1 were cultured in growth medium, consisting of Dulbecco's Modified Eagle's Medium (DMEM) (ATCC cat: 30-2002) supplemented with $10 \%$ newborn calf serum (NCS) (Equitech-Bio SNBU30-0500), 100UI/mL penicillin and 100 $\mu \mathrm{g} / \mathrm{mL}$ streptomycin. Cell cultures were incubated at $37^{\circ} \mathrm{C}$ in a humidified $5 \% \mathrm{CO}_{2}$ and $95 \%$ air incubator. The medium was replaced every 2-3 days. Adipocyte differentiation of 3T3L1 cells was induced using a hormonal cocktail. When the cultures reached confluency (day 0), cells were treated with differentiation medium containing DMEM supplemented with 10\% fetal bovine serum (FBS ATCC, cat: 30-2020), 0.25 $\mathrm{mM}$ dexamethasone (Sigma-Aldrich -D4902), $5 \mathrm{mg} / \mathrm{mL}$ insulin (Sigma-Aldrich-I3536) and $0.5 \mathrm{mM}$ isobutylmethylxanthine (IBMX, Sigma-Aldrich-I7018). At day 2, the medium was replaced with adipogenic medium containing DMEM supplemented with 10\% FBS and $5 \mathrm{mg} /$ $\mathrm{mL}$ insulin, for an additional 3 days, at which time $>90 \%$ of the cells were mature adipocytes with accumulated fat droplets.

Oil red O staining . Oil red O staining method by Ramírez et al. (1992), with minor modifications was used. The purpose of this technique was to identify the intracytoplasmatic lipid droplets on 3T3-L1 adipocytes. Seven days after the induction of adipocyte differentiation (day 8), Petri dishes were washed with PBS 1X (ATCC cat: SCRR-2201) twice and fixed with $4 \%$ paraformaldehyde (Sigma-Aldrich-P6148) for 20 minutes, at room temperature. Subsequently, cells were washed with PBS 1X three times. Five percent Oil red $\mathrm{O}$ solution in propyleneglycol was added for $60 \mathrm{~min}$ at room temperature. Thereafter dishes were washed extensively with distilled water, allowing drying for its later analysis and observation on bright field inverted microscope (Axiovert 25, Carl Zeiss) (10X, 32X, 40X) and take pictures. This assay was performed in triplicate.

Counterstaining with hematoxylin . Seven days after the induction of adipocyte differentiation (day 8), Petri dishes were washed with PBS 1X twice and fixed with $4 \%$ paraformaldehyde for $20 \mathrm{~min}$, at room temperature. Subsequently, cells were washed with PBS 1X three times. Five percent Oil red $\mathrm{O}$ solution in propyleneglycol was added for $30 \mathrm{~min}$ at room temperature. Afterward dishes were washed extensively with distilled water until rinses "clean". Thereafter Harris's hematoxylin was added for one minute and the dishes were rinsed with warm tap water until rinses "clean". Finally drying was allowed, in order to observe, analyze the bright field inverted microscope (10X, 32X and 40X) and take pictures. This was performed in triplicate.

Resveratrol treatment . Seven days after the induction of adipocyte differentiation (day 8), adipocytes were treated with RSV (TOCRIS BIOSCIENCE cat: 1418) at 25 and $50 \mu \mathrm{M}$, for 48 hours. Subsequently intracytoplasmic lipids were stained with Oil Red O (Sigma-Aldrich cat: O1516), mitochondrial staining and flow cytometry with 
Mitotracker Green FM (Life technologies cat: M7514).

Mitochondrial staining . 3T3-L1 adipocytes were seeded in P60 Petri dishes with cover glass on the bottom, in order to allow adhesion and cell confluence. Seven days after initiation of differentiation (day 8), Petri dishes with 3T3-L1 cells, labeled as control, $25 \mu \mathrm{M}$ and $50 \mu \mathrm{M}$, were washed with PBS twice. Mitotracker Green FM subsequently was added at concentration of $40 \mu \mathrm{M}$ in serum-free DMEM and incubated for 45 minutes in the incubator at $37^{\circ} \mathrm{C}$ and $5 \% \mathrm{CO}$. After this time 3T3-L1 adipocytes were washed with PBS four times and proceeded to fix them with $4 \%$ paraformaldehyde for $20 \mathrm{~min}$. After cells were washed four times with PBS. Coverslip from the Petri dish was removed and mounted on a glass slide which previously few drops of glycerol in PBS (3:1) were placed. Thereafter, we proceeded to analyze the samples on Leica confocal microscopy. This was performed in triplicate.

Flow cytometry. Seven days after initiation of differentiation (day 8) a cell suspension was obtained, which was centrifuged at $1500 \mathrm{rpm}$ for 5 minutes, the supernatant was decanted and Mitotracker Green FM added at concentration of $100 \mu \mathrm{M}$ and incubated for 60 minutes at room temperature. After this time, adipocytes were washed with PBS and fixed with 3\% formaldehyde for 20 minutes at room temperature and then were washed with PBS again. These cells were resuspended in FACS Flow solution for reading and analysis on a Becton Dickinson flow cytometer (FACS Calibur; BD Biosciences, CA, USA). The analysis was performed three times in quintuplicate.

\section{RESULTS}

Expanding preadipocytes were characterized as adherent cells and elongated cells with cytoplasmic extensions (Fig. 1A). Cells culture reached an adequate confluence $72 \mathrm{~h}$ post seeding, requiring a passage. After passage 5, preadipocytes were undergone into mature adipocytes differentiation protocol of eight days, noting in the first 24 hours that cells were clustered and formed growing points without exhibiting changes in morphology. After 48 hours of

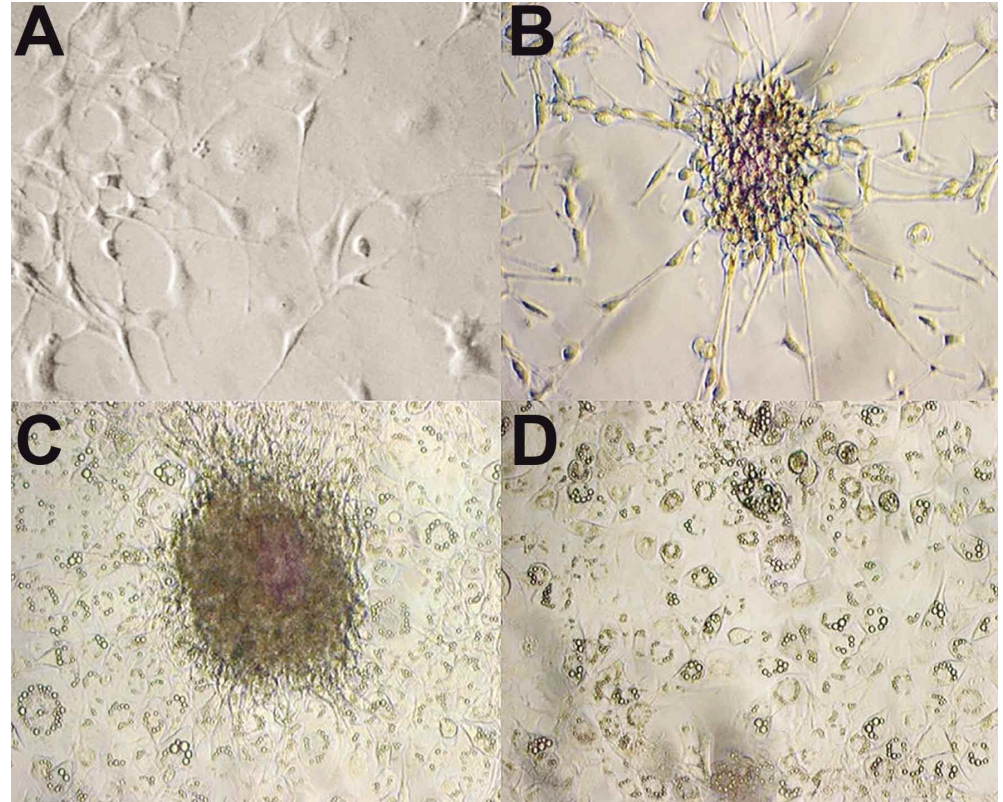

Fig. 1. Expanding and differentiating preadipocytes (100X). A. Elongated preadipocytes with cytoplasmic extensions. B. Preadipocytes at 48 hours of differentiation forming growth points. C. Preadipocytes at day four of differentiation, the presence of lipid vacuoles and polyhedral morphology is shown. D. Differentiated adipocytes at day six of differentiation, showing increased lipid vacuoles.

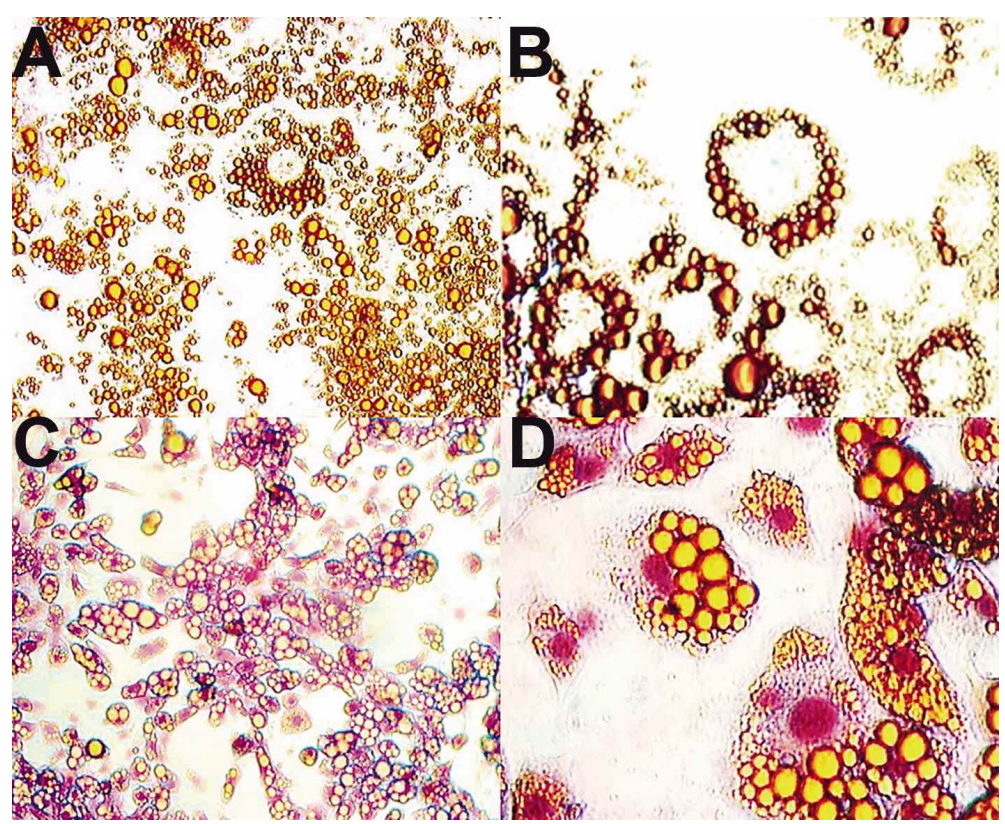

Fig. 2. Differentiated mature adipocytes. A and B. Oil red O stain in differentiated mature adipocytes, watching lipid vacuoles (100X and 400X). C and D. Oil Red $\mathrm{O}$ counterstained with hematoxylin that enables to locate lipid vacuoles around the adipocytes nuclei (100X and 400X).

differentiation, growing points showed confluency (Fig. 1B). By the $4^{\text {th }}$ day of differentiation, growth points began to disintegrate and elongated cells changed to a polyhedral morphology increasing their diameters as 
well as the emergence of vacuoles within the cytoplasm (Fig. 1C), and on the 6th day of differentiation, all cells in culture acquired a polyhedral morphology with a remarkable accumulation of intracytoplasmic lipid vacuoles, which are characteristic of differentiated adipocytes (Fig. 1D). Preadipocytes remained their differentiation capacity until passage 18 . manner (Fig. 4), obtaining similar results in flow cytometry in a quantitative manner, in this assay a tendency toward reduction in fluorescence intensity of the adipocytes treated with RSV was observed in respect to the control group. However, there was no significant difference between groups (Fig. 5).

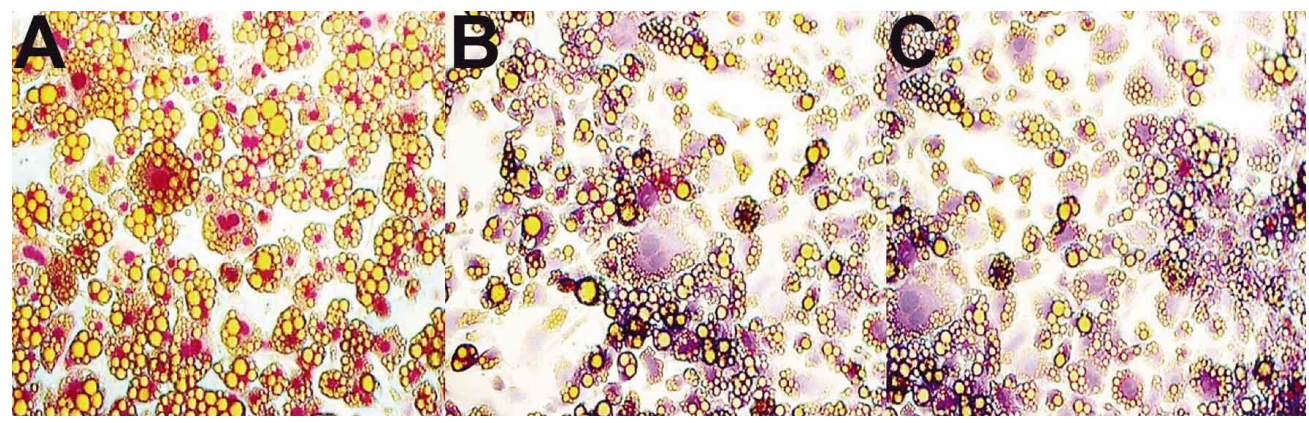

Fig. 3. Effect of RSV in differentiated mature adipocytes (100X). A. Control Group with abundant lipid vacuoles. B and C. Differentiated mature adipocytes treated with $25 \mu \mathrm{M}$ and $50 \mu \mathrm{M}$ of RSV respectively, with a notable decline in lipid vacuoles with respect to the control group.

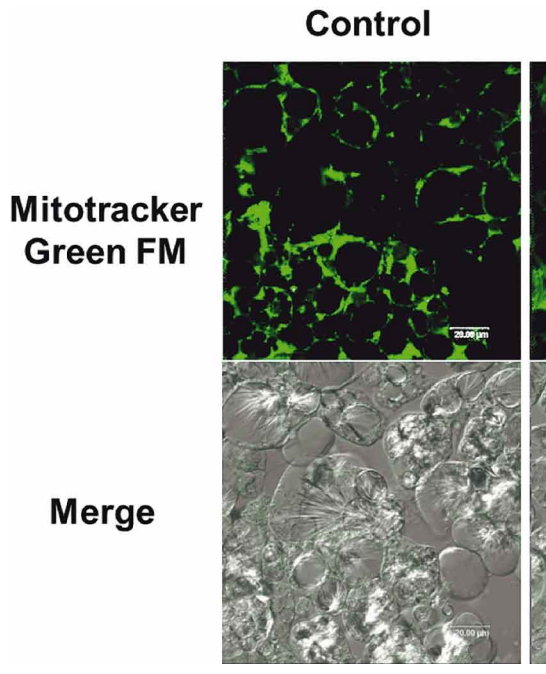

$50 \mu M$
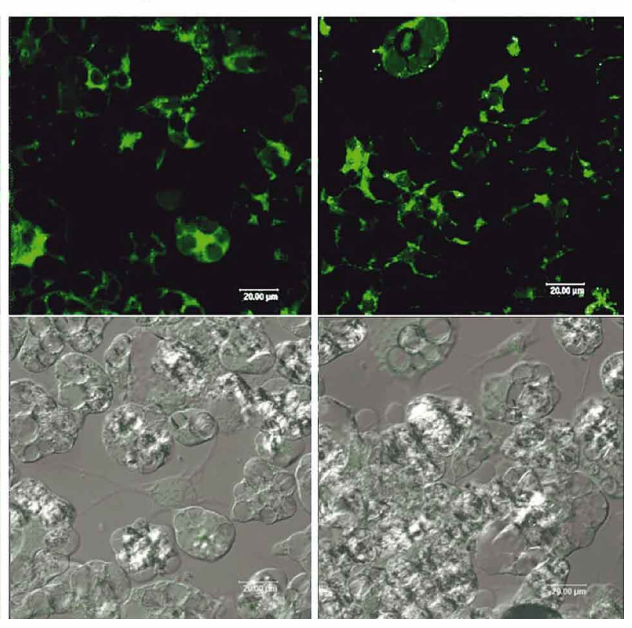

Fig. 4. Mitochondrial activity in adipocytes treated with RSV (400X). Qualitative decrease in mitochondrial activity in differentiated mature adipocytes treated with RSV, using the differential interference contrast (DIC) microscopy, also known as Nomarski.
The differentiated mature adipocytes stained with oil red $\mathrm{O}$ maintained their polyhedral morphology and the lipid vacuoles were identified by their red coloration, characterized by being small and multiple circling the nucleus of adipocyte (Fig. 2).

After the RSV exposure in mature adipocytes differentiated at concentrations of 25 and $50 \mu \mathrm{M}$, morphological changes were observed in the exposed adipocytes like decrease in size and content of lipid vacuoles in comparison with the control group not exposed to RSV (Fig. 3).

Concerning with mitochondrial staining, a qualitative decrease in mitochondrial activity of differentiated mature adipocytes treated with RSV was observed, in a dose-dependent

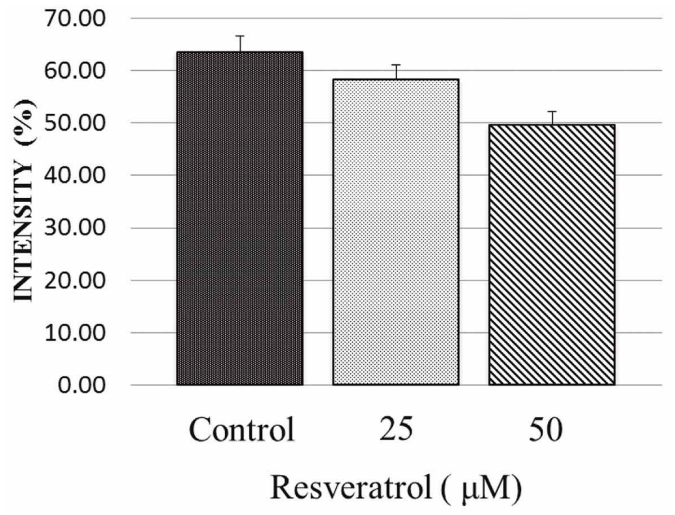

Fig. 5. A trend towards a decrease in fluorescence intensity of differentiated mature adipocytes treated with RSV was shown in a dose-dependent manner. However, there was no significant difference between groups $(\mathrm{P}=0.3679)$. 


\section{DISCUSSION}

Obesity is a risk factor for various types of diseases such as diabetes, hypertension and other cardiovascular diseases (Gregoire). Although there are a large number of studies dedicated to research the causes and prevention of obesity, its prevalence has increased in recent decades (Kopelman). Obesity is determined by the hypertrophy of white adipose tissue due to an imbalance between supply and demand of energy. Mitochondria are an integral part of normal cell function because they are responsible for energy production from TAG in eukaryotic cells (Frayn et al., 2006). Studies in adipose tissue of obese mouse ob/ob and $\mathrm{db} / \mathrm{db}$, it was determined that these presented a reduced mitochondrial mass and function (Rong et al., 2007). Due to excessive energy storage in adipose tissue of obese patients, it is useful to design strategies that allow us to increase the mitochondrial content and activity in adipocytes.

RSV is a polyphenol content primarily in red grapes, it has shown to reduce lipid synthesis in the liver of rats (Pervaiz, 2003) and adipocytes (Rayalam et al.) 3T3L-1 (Zhang et al., 2012), the last mentioned have been widely used as an in vitro model of adipogenesis. There is little scientific evidence and controversy about the effect RSV in mature 3T3-L1, mainly at mitochondrial level.

In this study we determined that the RSV decreased the lipid content in the cytoplasm of mature adipocytes differentiated as demonstrated by Rayalam et al., thereby the evidence of anti-adipogenic effect of RSV is supported, which is a consequence of the increased SIRT1 expression and the inhibitory effects of the adipogenic regulator PPARy (Rayalam et al.).

Furthermore in this study we treated differentiated mature adipocytes, differently to Zhang et al., who applied the RSV treatment through the entire preadipocytes differentiation, and it is worthwhile noting that they found a decreased lipid content as we did , but they did not determine the mitochondrial activity during the differentiation process.

Lagouge et al., showed that RSV promotes SIRT1 activation, and this improves mitochondrial function in mice; with this we can assume that the decrease in lipid content of differentiated mature adipocytes was a consequence of energy optimization carried out by mitochondria.

However, in this study we observed a decrease in mitochondrial activity, possibly by the decreased lipid content at the analysis time of this activity, so that, it is necessary to continue with similar protocols in order to analyze mitochondrial activity in immediate periods.

Rayalam et al., showed that cell viability decreased at $80 \%$ at high doses of RSV $(100 \mu \mathrm{M})$, however in our assays we employed doses at 75 and $50 \%$ lower.

Moreover, the PGC-1 $1 \partial$ is considered as a key regulator in energy metabolism (Gehart-Hines et al.) there are target proteins of this coactivator as mitofusin (MFN) types 1 and 2 . These proteins are localized to the outer mitochondrial membrane and they interact to coordinate the melting of the outer mitochondrial membrane of mitochondria opposite. Recent evidence has shown that this fusion directly regulates mitochondrial metabolism. In this way the knockdown of the two MFN by RNA interference, leading to the formation of fragmented mitochondria with lower oxygen consumption and decrease in membrane potential, that is, mitochondrial dysfunction (Chen et al.; Liang \& Ward, 2006). Based on this background, we could infer that decreased mitochondrial activity could be conditioned by the reduction in number of this organelle derived from the merger, being suitable for future studies to perform the expression analysis of MFN and determine its involvement in mitochondrial activity.

NORIEGA-GONZÁLEZ, J. E.; CHIRINO, Y. I.; MATAMIRANDA, M. M.; VÁZQUEZ-ZAPIÉN, G. J. \& SÁNCHEZ-MONROY, V. Efecto del resveratrol sobre la actividad mitocondrial en adipocitos maduros diferenciados. Int. J. Morphol., 33(3):1085-1092, 2015.

RESUMEN: La obesidad ha tomado dimensiones epidémicas globales y la Organización Mundial de la Salud estima que hay más de 1,000 millones de adultos con sobrepeso. Así mismo, la obesidad se ha caracterizado como la expansión del tejido adiposo blanco condicionada por la hipertrofia e/o hiperplasia de los adipocitos. La mitocondria es considerada la fuente de energía dentro del adipocito, debido a que contiene la maquinaria molecular que dirige, a través de diversas vías metabólicas, la transformación de la energía química en adenosíntrifosfato. La escasez de mitocondrias así como su disfunción en el adipocito, resulta en una acumulación excesiva de triacilgliceroles en el citoplasma, lo que condiciona un desequilibrio entre producción de energía y gasto energético. El resveratrol (RSV) es un polifenol que se encuentra en diferentes grupos de plantas y sus efectos se han asociado con la inducción de genes para la biogénesis mitocondrial. Se empleó un modelo de adipogénesis (in vitro) materializado por una línea celular de preadipocitos 3T3-L1, mismos que se diferenciaron a adipocitos maduros. Posteriormente se evaluó el efecto del 
RSV sobre la morfología, contenido lipídico y actividad mitocondrial en los adipocitos maduros diferenciados a través de las técnicas: microscopía invertida, confocal y citometría de flujo. El efecto del RSV sobre los adipocitos maduros diferenciados, se caracterizó por la disminución del contenido lipídico y consecuentemente de la actividad mitocondrial. Los preadipocitos 3T3-L1 conservaron la capacidad de diferenciación hasta el pase 18 . Por otra parte, el resveratrol a dosis de 25 y $50 \mu \mathrm{M}$ durante 48 horas en adipocitos maduros diferenciados, promueve una disminución en el contenido lipídico probablemente debido a un aumento de la actividad mitocondrial en las primeras horas de exposición al tratamiento, provocando la disminución de la actividad mitocondrial al término de 48 horas.

PALABRAS CLAVE: Preadipocitos; Adipocitos maduros diferenciados; Lípidos; Resveratrol.

\section{REFERENCES}

Atten, M. J.; Godoy-Romero, E.; Attar, B. M.; Milson, T.; Zopel, M. \& Holian, O. Resveratrol regulates cellular PKC alpha and delta to inhibit growth and induce apoptosis in gastric cancer cells. Invest. New Drugs, 23(2):111-9, 2005.

Austin, S. \& St-Pierre, J. PGC1? and mitochondrial metabolism-emerging concepts and relevance in ageing and neurodegenerative disorders. J. Cell Sci., 125(Pt. 21):4963$71,2012$.

Barger, J. L.; Kayo, T.; Vann, J. M.; Arias, E. B.; Wang, J.; Hacker, T. A.; Wang, Y.; Raederstorff, D.; Morrow, J. D.; Leeuwenburgh, C.; Allison, D. B.; Saupe, K. W.; Cartee, G. D.; Weindruch, R. \& Prolla, T. A. A low dose of dietary resveratrol partially mimics caloric restriction and retards aging parameters in mice. PLoS One, 3(6):e2264, 2008.

Bournat, J. C. \& Brown, C. W. Mitochondrial dysfunction in obesity. Curr. Opin. Endocrinol. Diabetes Obes., 17(5):446-52, 2010.

Cristancho, A. G. \& Lazar, M. A. Forming functional fat: a growing understanding of adipocyte differentiation. Nat. Rev. Mol. Cell Biol., 12(11):722-34, 2011.

Chen, H.; Chomyn, A. \& Chan, D. C. Disruption of fusion results in mitochondrial heterogeneity and dysfunction. J. Biol. Chem., 280(28):26185-92, 2005.

de la Lastra, C. A. \& Villegas, I. Resveratrol as an antioxidant and pro-oxidant agent: mechanisms and clinical implications. Biochem. Soc. Trans., 35(Pt. 5):1156-60, 2007.

De Pauw, A.; Tejerina, S.; Raes, M.; Keijer, J. \& Arnould, T. Mitochondrial (dys)function in adipocyte (de)differentiation and systemic metabolic alterations. Am. J. Pathol., 175(3):92739, 2009.

Frayn, K. N.; Arner, P. \& Yki-Järvinen, H. Fatty acid metabolism in adipose tissue, muscle and liver in health and disease. Essays Biochem., 42:89-103, 2006.

Gerhart-Hines, Z.; Rodgers, J. T.; Bare, O.; Lerin, C.; Kim, S. H.; Mostoslavsky, R.; Alt, F. W.; Wu, Z. \& Puigserver, P. Metabolic control of muscle mitochondrial function and fatty acid oxidation through SIRT1/PGC-1alpha. EMBO J., 26(7):1913-23, 2007.

Gregoire, F. M. Adipocyte differentiation: from fibroblast to endocrine cell. Exp. Biol. Med. (Maywood), 226(11):997$1002,2001$.

Guh, D. P.; Zhang, W.; Bansback, N.; Amarsi, Z.; Birmingham, C. L. \& Anis, A. H. The incidence of co-morbidities related to obesity and overweight: a systematic review and metaanalysis. B. M. C. Public Health, 9(1):122-32, 2009.

Hung, L. M.; Chen, J. K.; Huang, S. S.; Lee, R. S. \& Su, M. J. Cardioprotective effect of resveratrol, a natural antioxidant derived from grapes. Cardiovasc. Res., 47(3):549-55, 2000.

Kopelman, P. Health risks associated with overweight and obesity. Obes. Rev., 8(1):13-7, 2007.

Lagouge, M.; Argmann, C.; Gerhart-Hines, Z.; Meziane, H.; Lerin, C.; Daussin, F.; Messadeq, N.; Milne, J.; Lambert, P.; Elliott, P.; Geny, B.; Laakso, M.; Puigserver, P. \& Auwerx, J. Resveratrol improves mitochondrial function and protects against metabolic disease by activating SIRT1 and PGC1alpha. Cell, 127(6):1109-22, 2006.

Liang, H. \& Ward, W. F. PGC-1alpha: a key regulator of energy metabolism. Adv. Physiol. Educ., 30(4):145-51, 2006.

Pervaiz, S. Resveratrol: from grapevines to mammalian biology. FASEB J., 17(14):1975-85, 2003.

Picard, F.; Kurtev, M.; Chung, N.; Topark-Ngam, A.; Senawong, T.; Machado De Oliveira, R.; Leid, M.; McBurney, M. W. \& Guarente, L. Sirt1 promotes fat mobilization in white adipocytes by repressing PPAR-gamma. Nature, 429(6993):771-6, 2004.

Ramírez-Zacarías, J. L.; Castro-Muñozledo, F. \& Kuri-Harcuch, W. Quantitation of adipose conversion and triglycerides by staining intracytoplasmic lipids with Oil red O. Histochemistry, 97(6):493-7, 1992.

Rayalam, S.; Yang, J. Y.; Ambati, S.; Della-Fera, M. A. \& Baile, C. A. Resveratrol induces apoptosis and inhibits adipogenesis in 3T3-L1 adipocytes. Phytother. Res., 22(10):1367-71, 2008.

Rong, J. X.; Qiu, Y.; Hansen, M. K.; Zhu, L.; Zhang, V.; Xie, M.; Okamoto, Y.; Mattie, M. D.; Higashiyama, H.; Asano, 
NORIEGA-GONZÁLEZ, J. E.; CHIRINO, Y. I.; MATA-MIRANDA, M. M.; VÁZQUEZ-ZAPIÉN, G. J. \& SÁNCHEZ-MONROY, V. Effect of resveratrol on mitochondrial activity in differentiated mature adipocytes. Int. J. Morphol., 33(3):1085-1092, 2015.

S.; Strum, J. C. \& Ryan, T. E. Adipose mitochondrial biogenesis is suppressed in $\mathrm{db} / \mathrm{db}$ and high-fat diet-fed mice and improved by rosiglitazone. Diabetes, 56(7):1751-60, 2007.

Rosen, E. D. \& Spiegelman, B. M. Adipocytes as regulators of energy balance and glucose homeostasis. Nature, 444(7121):847-53, 2006.

Timmers, S.; Konings, E.; Bilet, L.; Houtkooper, R. H.; van de Weijer, T.; Goossens, G. H.; Hoeks, J.; van der Krieken, S.; Ryu, D.; Kersten, S.; Moonen-Kornips, E.; Hesselink, M. K.; Kunz, I.; Schrauwen-Hinderling, V. B.; Blaak, E. E.; Auwerx, J. \& Schrauwen, P. Calorie restriction-like effects of 30 days of resveratrol supplementation on energy metabolism and metabolic profile in obese humans. Cell Metab., 14(5):612$22,2011$.

World Health Organization (WHO). Fact sheet: obesity and overweight. Geneva, World Health Organization (WHO), 2015. Available from: http://www.who.int/mediacentre/factsheets/ fs311/en/

Zhang, X. H.; Huang, B.; Choi, S. K. \& Seo, J. S. Anti-obesity effect of resveratrol-amplified grape skin extracts on 3T3-L1 adipocytes differentiation. Nutr. Res. Pract., 6(4):286-93, 2012.
Correspondence to: Jesús Emmanuel Noriega-González Laboratorio de Embriología

Escuela Médico Militar

Universidad del Ejército y Fuerza Aérea

México D.F., C.P. 11200

MÉXICO

Email: noriegaemgs@gmail.com

Received: 26-03-2015

Accepted: 15-07-2015 